\title{
Short stature due to growth hormone qualitative anomaly
}

INSERM

\section{Source}

INSERM. (1999). Orphanet: an online rare disease and orphan drug data base. Short stature due to growth hormone qualitative anomaly. ORPHA:629

Short stature due to growth hormone qualitative anomaly is characterised by growth retardation and short stature (despite the presence of normal or slightly elevated levels of immunoreactive growth hormone, GH), low concentrations of insulin-like growth factor-I (IGF-I) and a sig nificant increase in growth rate following recombinant GH therapy. Prevalence is unknown but only a few cases have been reported in the literature. The syndrome is caused by various mutations in the GH1 gene (17q22-q24) that result in structural GH anomalies and a biologically inactive molecule. Transmission is autosomal recessive. 